\title{
A Contrastive Analysis of Haplology Patterns in Modern Standard English and Modern Standard Arabic
}

\author{
Abd Ali Nayif Hasan \\ abdalinayhf@yahoo.com \\ Department of English, College of Basic Education, University of Babylon, IRAQ
}

\begin{abstract}
Phonologically speaking, each word in a language consists of one or more syllables. In both modern standard English (henceforth MSE) and modern standard Arabic (henceforth MSA), a syllable may be followed by an identical one. In this case, one of such syllables is eliminated. This phonological process is referred to as haplology. The present study aims at finding out similarities and differences of haplology patterns between MSE and MSA. Accordingly, a comparison of haplology patterns between such two languages has been conducted. This phonological phenomenon results in the fact that differences are more than similarities of such patterns between both languages. Additionally, it appears that all eliminated syllables in MSE consist of onset and centre without coda and that they occur only in a medial position. As far as MSA is concerned, all elided syllables consist of onset and centre except the syllables [?it] and [zil] which consist of onset, centre and coda, and the syllables [un],[an] and [in] which consist of a centre and coda without onset. Some of such syllables can occur initially, others medially and that most of them occur finally. Such results lead to the conclusions that haplology patterns are mentioned to make pronunciation easy and that elision of some syllables in certain contexts investigates musical rhythm.
\end{abstract}

Keywords: haplology, syllable, elimination, contrastive analysis.

\section{Introduction}

The purpose of this study is to investigate the similarities and differences between MSE and MSA haplology patterns. This is necessary and beneficial for those interested in dealing with the phonological aspects especially the elision of a whole syllable in both languages.

Haplology is a phonological process whereby a whole syllable is elided when two similar syllables occur successively. It is originally related to Greek and identified by the American philologist Maurice Bloomfield in the 20th century (Webster, 2008). According to Trubetskoy (1969, p. 305), haplology is responsible of naming the nation which is regarded as the cradle of English, namely "England" whose original form is "Engla" and "land" where one of the repeated syllables (la)/lə/is eliminated.

Campbell (2004) points out that haplology is the phenomenon where the repeated sequence of sounds is rendered to a single occurrence. Consider the following example in which the syllable /li/ is elided because it is followed by the same one as in "humblely" /hımblili/ which becomes "humbly" /hımbli/. In the same respect, Trask (1996, p. 68) indicates that when the final syllable of a word is similar to the initial syllable of the following word, one of them is omitted as illustrated in 
the following example in which the syllable (ar) /a:/ is omitted: sagar ardo $\rightarrow$ sagardo.

Similarly, Bussmann (2006, p. 500) affirms that haplology is considered a special type of dissimilation where one of two identical neighboring syllables is eliminated as shown in the following example in which the syllable (ta) /tə/ is elided, e.g. preventative /priventativ/ $\rightarrow$ preventive/ priventiv/.

Crystal (2008, p. 224) states that haplology refers to the omission of successive sounds when pronounced at the same place of articulation. Consider the following instance where the two final neighboring consonants/t/and/s/are elided since both of them are alveolar, i.e., they are pronounced when the tip of the tongue touches or is near the alveolar ridge: cyclists /saiklists/ $\rightarrow$ /saiklis/. In the same sense, some psycholinguists assert that the term haplology is mentioned to indicate a tongue slip as in:

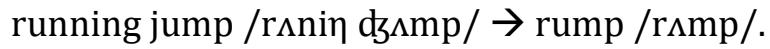
Some adverbs ending with (ly)/li/are preceded by the same syllable(le)/li/. In this respect, Trubetskoy $(1969$, p. 305$)$ points out that the syllable (le)/li/is eliminated as in: gentlely /dzentlili/ $\rightarrow$ gently /dzentli/and ablely /eiblili/ $\rightarrow$ ably /eibli/.

The examples below show elision of certain syllables:

a. mono nominal $\rightarrow$ monominal (the syllable (no) /nəu/ is elided),

b. urine /juərin/ analysis /ənæləsis / $\rightarrow$ urinalysis / juərinæləsis/ (/ən/ is elided),

c. library /laibreri/ $\rightarrow$ libry /laibri/ (the syllable /re/ is elided).

d. February /februri/ $\rightarrow$ Febry /febri/ (the syllable /ru/ is elided).

e. particularly /pətikjuləli/ $\rightarrow$ /pətikjuli/ (the syllable /lə/ is elided).

f. probably /probəbli/ $\rightarrow$ /probli/ (the syllable /bə/is elided).

g. representative /reprizentativ/ $\rightarrow$ representive /reprizentiv/ (/tə/ is elided).

h. authoritative /o:Oorətətiv/ $\rightarrow$ authoritive /o:Oorətiv/ (the syllable /tə/ is elided)

(Hornby, 1978).
Consonants can be elided where a word ends with consonant sounds similar to the initial sounds of the following word. In this case, one or two of the final consonants of the first word are elided as illustrated in the following instances:

a. just stay away /dj^st stei əwei/ $\rightarrow$ /d $\Lambda$ stei əwei/ (/s/ and /t/ are elided),

b. safe from /seif from/ $\rightarrow$ /seifrəm/ (/f) is elided),

c. from me /frəm mi/ $\rightarrow$ /frəmi/ (/m/ is elided),

d. newspaper route /nju:speipər ru:t/ $\rightarrow$ /nju:speipəru:t/ (/r/ is elided),

e. part taking /pa:t teikin/ $\rightarrow$ /pa:teiki $/$, (/t/ is elided),

f. last time /la:st taim/ $\rightarrow$ /la:staim/ ( $/ \mathrm{t} /$ is elided $)$, and

g. what to do /wot tə du:/ $\rightarrow$ /wotədu:/ (Jespersen, 1965, pp. 229-231).

Some examples are stated to show that haplology is mentioned to refer to the reduction of two consonants different only by voice (haplology with voice assimilation) as in:

a. cupboard / $\mathrm{k} \Lambda$ bəd/ (/p/ is assimilated to $/ \mathrm{b} /$ ).

b. sit down /sidaun/ (/t/ is assimilated to $/ \mathrm{d} /$ ).

c. black guard /blæga: $\mathrm{d} /(/ \mathrm{k} /$ is assimilated to $/ \mathrm{g} /$ )

(ibid).

As far as syllable elision in derivative words is concerned, Raffelsiefen (1996) affirms that similar onsets in neighboring syllables are not permissible in derivative words as illustrated in the following instances:
a. femininize /feməninaiz/ $\rightarrow$ feminize /femənaiz/,
b. minimimize /minimimaiz/ $\rightarrow$ minimize /minimaiz/,
c. metathesisize /metəӨisisaiz/ $\rightarrow$ metathesize /metəӨisaiz/, and
d. emphasisize /imfəsisaiz/ $\rightarrow$ emphasize /imfəsaiz/.

In these examples, the medial syllables such as /ni/, /mi/ and /si/ are elided because they are adjacent to syllables beginning with 
the same onsets such as $/ \mathrm{n} /, / \mathrm{m} /$ and $/ \mathrm{s} /$ respectively.

There is a relationship between Stress, which is defined as the force by which the syllable is uttered, and syllable elision. The word "probably" /probəbli/, for instance, is stressed on the first syllable. It is stated that the stressed syllable is more important and interesting than the unstressed syllables especially in understanding and producing words. In rapid speech, speakers are inclined to reduce the contrast in the vowels in the understood syllables. The production of a stressed syllable requires more muscular energy than that of the unstressed one. If a word such as "probably" is pronounced slowly and carefully, it'll take a form like "pro-bablee". But if it is pronounced faster, the medial unstressed vowel seems to be less distinct. Accordingly, the syllable /bə/is elided and the word is pronounced as "probly"/probli/ (The week.com/articles44 8898/why-say-probly and libry instead of probably and library).

There is a relation between the internal structure of a word and syllable elision. In this case, morphological haplology is known as a common process of inflection in which an affix is elided when the adjacent part of the stem is homophonous to it (Stemberger, 1981, p. 791). According to Katamba (2006, p. 57-58), haplology refers to the elimination of one of the similar elements. As far as morphological haplology is concerned, such elements form identical morphs that belong to identifiable morphemes as illustrated in the following examples:

a. Cats ("s" plural is attached to the noun).

b. The cat's ears (possessive "s" is attached to a singular noun).

c. The cats' ears (plural and possessive "s" co-occurring).

d. The oxen's ears (irregular plural combined with possessive "s").

Such examples show that when two similar morphs such as plural and possessive are attached to the noun, they involve the merger of the phonological content of the two morphs. This results in ambiguity as in example (c) above. It should be noted that the ambiguity does not occur in an irregular plural as in (d) above since its phonological form is different from the possessive one. In this sense, Stemberger (1981, p. 791) states that morphological haplology is considered as a dissimilated process that interacts with the morphological structure. Haplology is referred to as the elimination of similar phonetic or phonological forms in complex words. According to Booij (1983, p. 257), haplology can occur in any language whose morphological structure permits creating identical phonological sequences. Thus, it can be concluded that morphological haplology is considered to be universal in some sense with language specification in another sense.

Crystal (2008, p. 150) agrees with Bussmann (2006, p. 228) that dissimilation is a phonological process where one sound segment affects the articulation of a neighboring one so that they can become less alike or different. For instance, the sound /r/ in the Latin word "peregrinus" is dissimilated to /l/ to become "pilgrim" in English with some modifications such as: 1 . The first (e) changes into (i), 2. The second (e) is elided and 3 . The final letters (nus) change into (m).

Hudson (2000, p. 415) indicates that dissimilation is uncommon but it sometimes occurs in child speech as in the pronunciation of "chimney" / t imni/ where / $\mathrm{n}$ / changes into $/ \mathrm{l} /$ to become "chimley" because both $/ \mathrm{m} /$ and $/ \mathrm{n} /$ are nasal, i. e. they are pronounced when the soft palate is lowered and the air passes through the nasal cavity. Another example is that the first /l/ in "colonel" / kolənel/ is replaced by $/ \mathrm{r} /$. This type of dissimilation occurs between non-neighboring sounds. A special case of dissimilation is haplology where the second of two similar syllables is elided. This can be illustrated in the following instances where the syllable /si/ is elided:

a. Worcester /wusistə/ $\rightarrow$ /wustə/

b. Gloucester /glosistə/ $\rightarrow$ / glostə / (Wells, 2000, p. 165).

According to Angleo and Pyles (2005), a syllable is eliminated when followed by an identical syllable. They state examples where 
one of $/ \mathrm{r} /$ sounds is omitted as illustrated below:

Cate(r)pillar, cante(r)bury, rese(r)voir, terrest(r)ial.

Denham and Lobeck (2010) point out that the suffix-"al" is attached to nouns to form adjectives such as "person", "personal". When the noun ends with "l", the suffix-"al" changes into - "ar" as a result of dissimilation as in: module modular. In this case, Sihler (2000) points out that such a phonological change results in a decrease of similarity between adjacent segments.

\section{Haplology in Modern Standard Arabic}

Haplology is a phonological phenomenon whereby a heavy pronunciation of a word is reduced by means of eliminating a syllable so that such a word can be easily pronounced. Such an elimination can be initial, medial and final. In addition, sometimes a whole word is elided and what remains is only an affix.

\section{Initial Elision}

Initial elision refers to the elision of a syllable at the beginning of a word as illustrated in the following examples:

[tata?ammalu] $\rightarrow$ [ta?ammalu]. She hopes... .

[tatașaaraçu] $\rightarrow$ [tașaaraçu]. She quarrels....

In such examples, the initial syllable [ta] is elided since it is followed by the same syllable in the same word (Al-Hamlaawi, 1988, p. 60).

The initial syllable [fa] in the word [fallaahu] is elided as in:

[waman yafçalu xayran Pallaahu yanșuruhu]. One who does a good work, God will assit him. It is worth noting that the word [?allaahu] is originally [fallaahu] where the prefix [fa] is elided (Ibn Jinni, 1376H. p. 188).

As regards with a regular elision, an initial syllable beginning with a glottal stop such as [?it] is elided as in: [?ittax̧ðtu] [taxaðtu] (Al-
Andulusi, 2002, p. 157). This can be illustrated in the following saying: [taxiðtu qawla llaahi daliilan]. I have taken the God's saying a guide. In this example, the initial word [taxiðtu] is originally [?ittaxaðtu] where the initial syllable [?it] is omitted. In addition, the vowel sound [a] after [x] changes into [i]. In the same respect, Sibawayhi (1982, p. 439) points out that some Arabs elide the initial syllable [?it] in their saying as in:

[taqaa llaaha rajulun façala xayran]. A man who has done a good work will believe in God piously. Thus, the initial word [taqaa] is originally [?ittaqaa].

\section{Medial Elision}

Medial elision indicates that a syllable in the middle of a word is elided as illustrated in the following examples:

a. [masistu] $\rightarrow$ [mastu]. I have touched... . [hasistu] $\rightarrow$ [hastu] I have sensed. (Ibn Aqeel, n.d, p. 246). Such examples show that the medial syllable [si] is elided.

b. [maa?anta lmar?u lturdaa wilaayatuhu]. You are not the man whose government is satisfied. In this example, the word [?lturdaa] is originally [?llaði turdaa] where the medial syllables [la] and [ði] are elided. According to Al-Sawwar (n.d., p. 366), such an example shows a dialectal phenomenon of standard Arabic which is not taken into consideration by the old Arab linguists. Such a process is common among the Arab tribes because they are inclined to lessen the muscular effort in the production of the words they pronounce.

c. [qaala tafaalaa: waqad xaaba man dassaahaa]. Allaahu says: And he will indeed fail who corupts it (Shakir, 2005, p. 694). The word [dassaahaa], in this instance, is originally [dasasahaa] in which the first [s] is geminated, the second short vowel [a] is lengthened to become [aa] and the third syllable [sa] is elided. As far as regular elision is concerned, the word [yastatiiçu], he can .... is subjected to two types of elision one of which is the elision of the medial syllable [ta] so that such a word is pronounced [yastiiçu]. The other elided sounds in this word are the short vowel [a] of the second syllable [ta] and the consonant [t] of the third syllable [tii]. Thus, 
this word is pronounced [yastiiçu] (Sibawayhi, 1982, pp. 482 - 3).

d. The medial syllable [na] is elided from verbs when the nominative [n] and emphasis [n] come together as in: [ tukaððibuunani] [ tukaððibuuni] you don't believe me. It is noteworthy that the [n] in the elided syllable expresses the nominative case. The elision of such a syllable makes it easy to pronounce the word (Al-Jundi, 1965; Al-Andulusi, 2002, p. 369).

e. The medial syllable [nu] in the phrase [banu lçanbar] and other similar words is eliminated so that such a phrase will become a single word pronounced as [balçanbar]. This type of elision is mentioned to make the Arabs fast in their speech (Al-Zamakhshari, n.d., p. 155).

f. The medial syllable [na] in the phrase [mina l?asri] from prison, is elided. As a result, the phrase becomes a single word such as [mil?asri] (Al-Azhari,1325H., p. 29). In the same respect, the medial syllable [la] in the phrase [çala lmaa?i] at water, is elided. Accordingly, such a phrase becomes a single word pronounced as [çalmaa?i] (ibid).

g. Sibawayhi (1982, p. 349) points out that the medial syllable [yuu] in the word [madyuun] in debt, is eliminated so that such a word will become [madiin] since Arabs find the pronunciation of [ii] easier than that of [uu].

\section{Final Elision}

Final elision refers to the elimination of a syllable at the end of a word. Arabic language is considered one of the languages where the elision of a final syllable makes the preceding vowel long as illustrated in the following instances:

a. The final syllable [ya] in the word [hiya] she is, is eliminated as in: [?ið hiya] which becomes [?ið hii] (Sibawayhi, 1982, p. 9). It can be noted that, in this example, the short vowl [i] changes into long [ii].

b. The final syllable [zil] in the word [?lmanaazil] houses, is eliminated as in: [darasa lmanaazil] which becomes [darasa Imanaa] (Ibn Yaeesh, 1928, p. 405; AlEsterabaathi, n.d., p. 498). c. The final syllable [na] in the word [kallaðiina] is omitted. Thus, the word becomes [kallaðii] as in: [qaala taçaalaa: waxuḍtum kallaðii xaaḍu] Allaahu says ... and you entered into vain discourses like the vain discourses in which entered those before you... (Shakir, 2005, p. 246).

d. The final syllable [mu] in the word [ya?tamimu] is elided so that the word will become [ya?tami] as in: [wa?ammaa bi?açmaali lmuxlișiina faya?tami] (Ibn Mandhoor, n.d., p. 297).

e. The final syllable [taa] in the word [mataa] when, is eliminated. Accordingly, the word becomes [ma] as in: [?ilaa mataa]? To what time?, which becomes [?ilaama]. It is affirmed that this type of elision occurs in poetry so that it can investigate the musical rhythm of the word (ibid).

f. The final syllable [ni] in the word [yadaani] two hands, is eliminated. Thus, such a word becomes [yadaa] as in: [qaala taçaalaa: tabbat yadaa $\mathrm{Pbi}$ lahab watab] Allaahu says: Perdition overtake both hands of $\mathrm{Abu}$ Lahab, and he will perish (Shakir, 2005, p. 705).

g. The final syllable [ka] in the word [qalaaka] is omitted. Thus, such a word becomes [qalaa] as in: [qaala taçaalaa: maa waddaçaka rabbuka wamaa qalaa]Allaahu says: Your Lord has not forsaken you, nor has He become displeased (Shakir, 2005, p. 696). The reason behind such a type of elimination is to investigate the beautiful rhythm and to attract the attention of readers and listeners (vb.arabsgate.com/ show thread php?t=542777).

$h$. When the speaker stops at the end of a word, he elides the short vowels such as [u], [a] or [i] in addition to the sound [n] which represents [tanwiin] as in:

1. [haaðaa zaydun] $\rightarrow$ [haaðaa zayd] 'This is Zaid'.

2. [saafadtu zaydan] $\rightarrow$ [saaSadtu zayd] 'I helped Zaid'.

3. [marartu bizaydin] $\rightarrow$ [marartu bizayd] 'I passed Zaid'.

Such a type of omission is mentioned to make the pronunciation easy (Anees, 1994, p. 135). 
Table 1. Transliteration Symbols for (MSA) Vowels and Some Consonants

\begin{tabular}{|c|c|c|c|}
\hline $\begin{array}{l}\text { Arabic } \\
\text { alphabet }\end{array}$ & Symbol & Example & Meaning \\
\hline i & $?$ & ?amal & hope \\
\hline$\varepsilon$ & S & Silm & science \\
\hline$j$ & 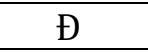 & ðahab & gold \\
\hline ق & $Q$ & qalam & pencil \\
\hline ج & $\mathrm{J}$ & jamal & camel \\
\hline$\tau$ & h & $h u b$ & love \\
\hline$\dot{\tau}$ & $x_{3}$ & xubz & bread \\
\hline b & $t$ & țiin & mud \\
\hline ص & $\underline{S}$ & ayf & summer \\
\hline ض & $\mathrm{d}$ & dayf & guest \\
\hline ش ش & $\int$ & fams & sun \\
\hline ي & Y & yad & hand \\
\hline 9 & W & ward & rose \\
\hline الضمة & $\mathrm{U}$ & kutub & books \\
\hline ضمة طويلة & $\mathrm{Uu}$ & fuul & beans \\
\hline الفتحة & $\mathrm{A}$ & kataba & he wrote \\
\hline مد طويل & $\mathrm{Aa}$ & kaatib & writer \\
\hline الكسرة & I & $\sin$ & tooth \\
\hline كسرة طويلة & ii & fiil & elephant \\
\hline Diphthongs & $\begin{array}{l}\text { ay } \\
\text { aw }\end{array}$ & $\begin{array}{c}\text { bayt } \\
\text { mawt }\end{array}$ & $\begin{array}{l}\text { house } \\
\text { death }\end{array}$ \\
\hline
\end{tabular}

\section{Methodology}

The present study is mainly concerned with phonology as it is related to analyzing and contrasting the syllables elided in both (MSE) and (MSA). This linguistic phenomenon can be investigated by surveying the literature of both languages so that data can be collected. The researcher has adopted English and Arabic reliable references as well as online ones to find out haplology patterns (elided syllables) in (MSE) and (MSA). In addition, English phonemic transcription of the examples stated in this paper has been taken from "Oxford Advanced Learner's Dictionary of Current English". (MSA) transliteration depends on a list of vowels and some consonants. Contrasting the elided syllables in (MSE) and (MSA) shows that there are six similar syllables elided in both languages. Additionally, some syllables are elided in (MSE) without counterparts in (MSA) and vice versa.

\section{Results and Discussion}

This section is concerned with contrasting the syllables elided in both (MSE) and (MSA) so that similarities and differences between (MSE) and (MSA) elided syllables can be conducted.

There are six syllables elided in both (MSE) and (MSA). They are stated and discussed in the following points:

1. The syllable /tə/

The syllable /tə/ consists of the onset / $\mathrm{t} /$ and the centre /ə/. In (MSE), such a syllable occurs only medially as in: representative /reprizentətiv/ representive /reprizentiv/. In (MSA), the syllable [ta] occurs initially, medially and finally as in:

a. [tata?ammalu] [ta?ammalu] She hopes ... (initial elision)

b. [yastațiiçu] [yasțiiçu] He can ... (medial elision)

c. [?ilaa mataa]? [?ilaama]? To what time? (final elision)

2. The syllable /lə/

In both (MSE) and (MSA), the syllable /lə/ occurs in medial positions as in:

a. English: particularly / pətikjuləli/ /pətikjuli/.

b. Arabic: [çala lmaa?] [çalmaa?] At water.

3. The syllable /nə/

In (MSE), the syllable /nə/ occurs medially as in:

a. urine analysis /juərin ənæləsis/ urinalysis /juərinæləsis/. In (MSA), the syllable [na] occurs medially and finally as in:

b. [tukaððibuunani] [tukaððibuuni]You don't believe me. (medial elision)

c. [kallaðiina] [kallaðii] (final elision).

4. The syllable /si/

The syllable /si/ occurs medially in both (MSE) and (MSA) as in:

a. English: Worcester /wusistə/ /wustə/.

b. Arabic: [masistu] [mastu] I have touched

5. The syllable /ni/

In (MSE), the syllable /ni/ occurs medially as in femininize /femininaiz/ $\rightarrow$ feminize 
/feminaiz/. In (MSA), such a syllable occurs finally as in [yadaani] $\rightarrow$ [yadaa] 'two hands'.

6. The syllables /nəu/ and [nu] occur medially in both (MSE) and (MSA) respectively as follows:

English: mono nominal /monəu nominl/ $\rightarrow$ /monominl/.

Arabic: [banu lçanbar] $\rightarrow$ [balçanbar].

It is worth noting that the syllables elided in all the examples stated above in both (MSE) and (MSA) have no coda and that their centres are realized by short vowels except the syllable [taa] in (MSA) whose centre is a long vowel.

In (MSE), certain syllables are elided with no counterparts in (MSA) as illustrated in the following examples:

1. The syllable /li/

The syllable /li/ is represented by the two letters (l) and (e) which is medially elided as in: humblely /h $\Lambda$ mblili/ $\rightarrow$ humbly /h^mbli/.

2. The syllable /mi/

The syllable /mi/ is medially elided as in: minimimise /minimimaiz/ $\rightarrow$ minimise /minimaiz/.

3. The syllable /bə/

The syllable /bə/ is medially elided as in: probably /probəbli/ probly /probli/.

4. The syllable /re/

The syllable / re/ occurs in the middle of the word "library" from which it is elided as in: library /laibreri/ libry /laibri/.

5. The syllable /ru/

The syllable /ru/ occurs in the middle of the word "February" from which it is elided as in: February /februri/ Febry /febri/.

6. The syllable /a:r/

The syllable /a:r/ is realized by the two letters (a) and (r) in the final position of the word "sagar" /saga:r/. This syllable is elided as follows:

sagar ardo /saga:r a:d $\partial \mathrm{u} / \rightarrow$ sagardo

/saga:d $\partial \mathrm{u} /$
In (MSE), some consonants are elided because they are adjacent to identical ones as illustrated in the following instances:

1. /st/ as in: just stay /dgAst stei/ $\rightarrow$ /dzAstei/

2. /f/ as in: safe from /seif frəm/ $\rightarrow$ /seifrəm/

3. $/ \mathrm{m} /$ as in: from me /frəm $\mathrm{mi} / \rightarrow$ /fromi/

4. /r/ as in: newspaper route /nju:speipə(r) ru:t/ $\rightarrow$ /nju:speipəru:t/

In certain English words, two adjacent consonants are different in voice in that the first one is voiceless whereas the second is voiced. Accordingly, the first voiceless consonant is not pronounced, i. e. it is elided or assimilated in the second voiced consonant as in:

/pb/ /b/ as in: cupboard /kıbəd/, Hepburn /hebən/.

/td/ /d/ as in: sit down /sit daun/, /sidaun/. /kg/ /g/ as in: black guard /blæk ga:d/ / blæga:d/.

Such examples are known as voice assimilation.

In (MSA), certain syllables are elided with no counterparts in (MSE) as in:

1. The syllable [?it]

The syllable [?it] comprises the onset [?], the centre [i] and the coda [t]. Such a syllable occurs in the initial position of the (MSA) words. It is elided as in: [?ittaxaðu] [taxaðu].

2. The syllable [fa]

The syllable [fa] occurs in the initial position of some words such as [?allaahu] from which it is elided as in: [fallaahu] [?allaahu].

3. The syllable [sa]

The syllable [sa] occurs in the medial position of certain Arabic words where it is eliminated as in: [dassasahaa] [dassaahaa]. 
4. The syllables [la] and [ði]

The syllables [la] and [ði] occur at the end of the word [?allaði] which can be elided in the following example: [?allaði turdaa] [?alturdiaa].

5. The syllable [zil]

The syllable [zil] occurs at the final position of the word [?almanaazil] houses, which can be elided as in: [?almanaazil] [?almanaa].

6. The syllable [mu]

The syllable [mu] is eliminated at the final position of certain Arabic words such as: [ya?tamimu] [ya?tami].

7. The syllable [yuu]

The syllable [juu] occurs in the medial position of some Arabic words from which it is elided as in: [madyuun] [madiin].

8. The syllable [ya]

The syllable [ya] occurs at the end of certain Arabic words from which it is elided as in: [hiya] [hi:].

9. The syllable [ka]

The syllable [ka] occurs at the end of certain words from which it is elided as in: [qalaaka] [qalaa].

10. The syllables [un], [in] and an]

The syllables [un], [in] and [an] occur at the end of proper nouns from which they are elided when we stop at them. Consider the following examples: [zaydun], [zaydin] and [zaydan] [ zayd].

\section{Conclusion}

The contrastive analysis of haplology patterns in (MSE) and (MSA) leads to the fact that differences are more than similarities between such patterns. Also, it is concluded that all the elided syllables in (MSE) consist of onset and centre without coda and that they occur only medially. They are about eleven syllables six of which are similar to those occur in (MSA). All the elided syllables in (MSA) have no coda except the syllable [?it] which consists of onset, centre and coda, and the syllables [un], [an] and [in] which consist of a centre and coda without onset. Some of (MSA) elided syllables occur initially and medially but most of them occur finally. Haplology, as a linguistic phenomenon, is common among human languages especially (MSE) and (MSA) because people, in general, are always inclined to make their speech brief so that it can be easily pronounced and understood. Patterns of haplology are obviously represented in poetry where the rhyme of the poem urges the poet to eliminate a whole syllable or certain sounds so that the poem can be recited with a beautiful musical rhythm. This, of course, attracts the readers and listeners' attention and it makes the words strong and expressive.

\section{References}

Alego, John and Thomas Pyles (2005). The Origin and Development of the English Language. 5th Edition. Thomson.

Anees, Ibraheem (1994). [Fi llahajaati Içarabiyyati lqadiima]. 1st Edition. Beirut: [daarul- hadaaӨa].

Al-Azhari, Khalid (1325 H.).[ farhu ttaṢriih cala ttawdiih]. Cairo: AlAzhariyya Egyptian Press.

Booij, G. (1983). "Extra syllabicity and Lexical Phonology". The linguistic Review3: 257.

Bussmann, Hadumod (2006). Rutledge Dictionary of Language and Linguistics. London: Rutledge.

Campbell, Lyle (2004). Historical Linguistics: An Introduction. 2nd Edition. Mit Press.

Crystal, David (2008). A Dictionary of Linguistics and Phonetics. 6th Edition. Oxford: Blackwell Publishing.

Denham, Kristin and Ann Lobeck (2010). Linguistics for Everyone. Wadsworth. 
Al-Esterabaathi, Abi Al-Fdhaai'l Ruknul Deen Al-Hasan (n.d.).[Kitaab Jarh faafiyyat Ibnu Ihaajib]. Edited by Abdul-Mqsood Mohammad Abdul -Maqsood. 1st Edition. Seond Part. Cairo: Religious Culture Bookshop.

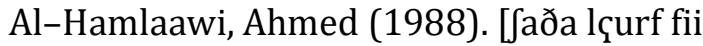
fan niȘȘarf]. Baghdad: Arraaya Press.

The Holy Qura'n.

Hornby, AS. (1978). Oxford Advanced Learner's Dictionary of Current English. Oxford: Oxford University Press.

Hudson, Grover (2000). Essential Introductory Linguistics. Oxford: Blackwell Publishers Inc.

Ibn Aqeel, Bahaa' uDdeen Abdullaah (n.d.). [Jarh Palfiyyat ?bn maalik]. Second Edition. Edited by Mohammad Muhyi Ddeen Abdul-Hameed. Cairo:[ Daarul-Fikr].

Ibn Jinni, Abul-Fath (1376 H.). [PalxaȘsaa?iṢ]. Edited by Mohammad Ali Al -Najjar. Cairo: General Committee of the Book.

Ibn Mandhoor (n.d.). [muçam lisaanul-\{arab]. Edited by yoosif Khayyaat and Nadeem Mareshli. Biruut: Daarul-Kutub.

Ibn Yaeesh, Muwaffaqu Ddeen (1928). [Jarḥul - MufaȘSal]. Edited by Mohammad Muneer. Cairo: AlMinbariyya Press.

Jespersen, Otto (1965). A Modern English Grammar on Historical Principles. Part 1 Sounds and Spellings. Britain: John Dickens and Co Ltd.

Al-Jundi, Ahmed Alamu Ddeen (1965). [?allahajaatul çarabiyya fi tturaa $\theta$ ]. Cairo.

Katamba, Francis and John Stonham (2006). Morphology. 2nd Edition. London: Macmillan.
Merriam-Webster's Word of the Day for February 6, 2008. Merriam Webster online. Retrieved 2008-02-06.

Raffelsiefen, Renate (1996). "Gaps in WordFormation". In Ursula Kleinhenz (ed.): Interfaces in Phonology. Berlin: Akademie-Verlag, 193-208.

Al-Sawwar, Yehya bin Ali (n.d.). [?aӨaru Pxtilaafi llahaajaati lçarabiyyati finnaḥu] MA Unpublished Thesis. Al-Riyadh: Central Library.

Shakir, M. H.(Trans) (2005). Holy Qur'an. Qum: Ansariyan.

Sibawayhi, Abu Bishr Amru bin Uthman Bin Qanbar (1982). [?l-Kitaab]. Edited by Abdul-Salaam Haroon. Beirut: [Daarul-Kutub].

Sihler, Andrew L. (2000). Language History: An Introduction. Amsterdam: John Benjamins.

Stemberger, J. (1981). 'Morphological Haplology', Language, 57, pp. 791-817.

Trask, R. L. (1996). Historical Linguistics. London: Arnold.

The week.com/articles448898/why-sayprobly and libry insteadof probably and library.

Trubetskoy, N. S. (1969). "Appendix ii: Thoughts on Morphology". In Baltaxe (trans.), Christiane A. M. Principles of Phonology. Berkeley and Los Angeles: University of California Press. P. 305. Vb.arabsgate.com/show thread.php?t=542777

Wells, John C. (2000). Longman Pronunciation Dictionary. 2nd Edition. https://archive.org

Al-Zamakhshari (n.d.). [?l - MufaȘȘal]. Beirut: [Daarul-Kutubil çilmiyya]. 